\title{
RITUAL NGALAB BERKAH DALAM MENCARI KEKAYAAN DI GUNUNG KEMUKUS1
}

\author{
Triyanto \\ University of Teuku Umar \\ Email: Triyanto3222@gmail.com
}

\begin{abstract}
Every society in the world has a culture, and every culture has is a system of beliefs held by the community. Likewise community actors in Kemukus ritual that has its own beliefs about how to find fortune by doing free sex. The conviction was strung in a ritual which known as ngalab berkah. This ritual begins from a myth that spoken by the RA Ontrowulan towards moksha as a royal family that promise to grant all requests of people who participated in Kemukus nyonggo wirang. The existence of this ritual is able to increase the local economy, as evidenced that is the emergence of jobs for the community. But it on the other hand it also cause negative impacts such as raises prostitution. It becomes an interesting phenomenon, because if this ritual is closed, then many people will be unemployed. Meanwhile if left unchecked, would be bad for society. To describe this ritual conception it was conducted qualitative research. The result is the people have a conception which is the influence of Hindu-Buddhist and animist dynamism, especially about the king who is believed to be a manifestation of God. Based on this conception ritual actors believe the myth, so that conception nyonggo wirang is a form of defense and the participation of actors ritual with the pathos of the character who is the royal family, so it is not impossible if the request will be met.
\end{abstract}

Keywords: Myths, Free sex, Kemukus, Wealth.

\section{PENDAHULUAN}

Dalam setiap diri manusia senantiasa ada suatu kepercayaan dan keyakinan bahwa ada sesuatu yang lebih kuat, misterius dan maha dahsyat (mysterium-tremendum) (Koentjaraningrat, 2010. 65). Dimana manusia tidak memiliki kemampuan untuk menundukkan atau bahkan mengendalikannya. Datangnya air bah, angin topan, gempa bumi dan letusan gunung berapi merupakan bencana besar yang manusia tidak sanggup menaklukkannya, maka manusia terpaksa berserah diri kepada suatu kekuatan maha dahsyat yang lebih kuat dari bencana itu. Karena itu

${ }^{1}$ Diambil dan dikembangkan dari Skripsi penulis berjudul Fungsi Ritus Hubungan Seks Bebas Pada Upacara Memohon Rejeki di Gunung Kemukus Kabupaten Sragen Jawa Tengah. Jurusan Antropologi Fakultas Sastra Universitas Udayana. Denpasar 
manusia mengenal dan mempercayai keberadaan Tuhan sang penguasa alam semesta.

Keyakinannya akan Tuhan sebagai penguasa alam semesta membuat manusia ingin bersandar akan segala hal yang tidak mampu diatasinya. Bencana dan segala kesulitan-kesulitan seperti kebutuhan hidup akan ekonomi, martabat, kedudukan sosial dan lain sebagainya memaksa manusia untuk berserah diri dan sebagai wujud baktinya manusia melakukan upacara-upacara keagamaan. Jelas bahwa upacara keagamaan tersebut diperlukan dalam upaya manusia memenuhi kebutuhan-kebutuhan asasi dalam setiap masyarakat manusia yang mengikuti sistem religi tersebut dan kebutuhan tersebut akan senantiasa ada walaupun ilmu pengetahuan dan teknologi yang dikuasai telah mencapai tingkat tertinggi (Koentjaraningrat, 2010. 97-98).

Demikian halnya dengan ritual "ngalab berkah" (mencari rezeki) di Gunung Kemukus Jawa Tengah. Ketidakmampuan manusia dalam persaingan mencari nafkah dan memenuhi kebutuhan hidup, telah memaksanya untuk melakukan sebuah ritual di Gunung Kemukus itu. Munculnya mitos yang ada juga sanggup mendatangkan penganut yang meyakini dari berbagai pelosok penjuru di tanah jawa dari Banten sampai dengan Surabaya. Bukan hanya logat bahasa yang membedakan tetapi juga plat kendaraan roda empat yang bukan saja "AD" turut mewarnai hiruk pikuknya ritual "ngalab berkah" tersebut.

Mitos itu berbunyi "sopo wae sing gelem teko marang makam iki kamongko tekane ing kene nyekar lan kanthi koyo dhemenane wong mau bakal dak kabulake panyuwunane" (barangsiapa mau datang ke makam padahal datangnya berziarah dan dengan "kesenangannya" maka permintaannya akan aku kabulkan) (Triyanto, 2000. 57), ini menjadi daya tarik tersendiri bagi mereka yang meyakininya.

Makna "dhemenane" pada mitos tersebut ternyata ditafsirkan dengan melakukan hubungan seks dengan orang lain, sebagaimana kisah kasih hubungan Pangeran Samudra dengan RA Ontrowulan dimana Ontrowulan diyakini sebagai istri selir dari ayah angkat Pangeran Samudra.

Ada yang ganjil apabila dirasakan, yakni pelaku ritual sangat tertarik untuk melakukan hubungan seks bebas dan bukan kerja keras membanting tulang apabila ingin mencari kekayaan, sedangkan hubungan seks bebas itu sesungguhnya dilarang oleh agama maupun peraturan pemerintah. Pelaku ritual seolah mengabaikan larangan agama yang menjadi keyakinan mayoritas masyarakat Kemukus. Pelaku ritual juga seolah mengabaikan norma dan larangan pemerintah dalam melakukan ritual ngalab berkah dengan seks bebas. Walaupun sebagian 
pelaku menganggap aktivitasnya difasilitasi oleh pihak-pihak tertentu yang beroperasi di sana. Tampaknya pelaku ritual memiliki keyakinan terhadap mitos yang lebih kuat dibandingkan keyakinannya terhadap agama, padahal agama mampu mengkaji berdasarkan pengetahuan empiris maupun ilham dan wahyu (Ahyadi, 2005. 1).

Keyakinan masyarakat baik pengunjung dari luar daerah maupun masyarakat setempat akan mitos itu semakin bertambah ketika semakin banyak pengunjung yang dianggap sudah berhasil. Ini menguatkan bahwa masyarakat pelaku ritual telah dipengaruhi oleh sosok yang dikuburkan di Kemukus ini. Selaras yang dikatakan Bakker bahwa orang mati memiliki pengaruh terhadap orang dan dunia saat ini (Bakker, 2009. 309). Pengaruh ini dalam konteksnya mitos di Kemukus juga ditunjukkan semakin banyaknya masyarakat yang terlibat dalam ritual ini baik dalam penyediaan fasilitas akomodasi, transportasi maupun hiburan, memaksa pemerintah untuk turut campur tangan dalam urusan ritual ini. Bahkan pemerintah daerah melalui Dinas Pariwisata akhirnya mengelola tempat tersebut sebagai obyek pariwisata religius, meskipun harus menanggung dampak negatifnya seperti munculnya praktik-praktik prostitusi di sekitar area obyek wisata.

Dampak negatif seperti munculnya prostitusi tersebut sangat jelas terasa di Kemukus, namun terkesan tidak ada upaya untuk menutup Kemukus sebagai tempat wisata religius. Dicurigai ada banyak pihak yang diuntungkan dengan keberlangsungan ritual "ngalab berkah" di Kemukus ini. Terbukanya lapangan pekerjaan yang luas dan peningkatan kesejahteraan masyarakat menjadi asumsi atas keberlangsungan ritual. Namun lapangan pekerjaan dan peningkatan kesejahteraan hanyalah sebuah pengaruh positif dari aktivitas ritual itu sendiri. Hal penting yang harus diketahui adalah mengapa ada masyarakat yang melakukan ritual "ngalap berkah" di Kemukus, dan jauh dari itu mengapa pelaku ritual memiliki kepercayaan terhadap mitos yang diyakini sebagai bentuk "nyonggo wirang" keluarga keraton, sehingga keinginan pelaku ritual akan dikabulkan atau terwujud oleh karena melakukan ritual ini. Hal terakhir adalah bagaimana masyarakat setempat dan pihak-pihak tertentu yang memiliki kekuatan di Kemukus seolah membiarkan ritual ini berlangsung.

Ritual "ngalab berkah" ini telah banyak yang melakukan penelitian dan menulis sesuai dengan sudut pandang keilmuan masing-masing. Dalam karya ilmiah ini, memposisikan ritual "ngalab berkah" dalam sudut pandang kajian antropologi religi yang lebih mendeskripsikan tentang kepercayaan atau keyakinan suatu umat/penganut terhadap sesuatu yang dianggapnya sesuatu itu mampu membawa atau memberikan suatu hal yang dapat memenuhi kebutuhan umat akan permasalahan hidupnya 
(Raho, 2014. 236). Sisi yang lain dapat dikembangkan sebagai kajian sosiologi agama yang membahas hubungan pengaruh timbal balik antara agama dan masyarakat sebagai penganut. Lebih spesifik adalah demi sebuah keyakinan seseorang mampu melakukan apa saja yang berdampak baik positif atau negatif pada masyarakat (Sindung, 2015. 29).

\section{Gunung Kemukus}

Dalam istilah orang Jawa, gunung adalah daerah yang memiliki letak yang lebih tinggi dari daerah lain, dari bagian atas sampai ke bawah berbentuk kerucut menyerupai caping. Sehingga dalam istilah kata "Gunung" dipakai juga untuk bukit, dan kata bukit sangat jarang bahkan tidak dipakai untuk memberi nama sebuah daerah yang berbentuk gunung tersebut. Dalam istilah Gunung Kemukus ini, gunung yang dimaksud sebenarnya adalah bukit (dalam bahasa Indonesia) namun masyarakat setempat menyebutkan sebagai gunung yang berada di Kemukus, maka nama tersebut adalah Gunung Kemukus (Triyanto, 2000. 25). Istilah ini serupa dengan orang Aceh dalam memberikan nama gampong (desa) dengan sebutan "Cot". Kata "Cot" mewakili penafsiran tentang sebuah daerah yang posisinya lebih tinggi dibandingkan dengan daerah lainnya, sehingga orang Aceh banyak memberi nama gampong dengan kata "Cot" seperti Cot Kandeh, Cot Darat, Cot Pluh, dan lainlainnya. Namun dalam terjemahan bahasa Aceh kata "Cot" yang berdiri sendiri dimaknakan sebagai tegak atau vertikal (Adnan dkk, 2000. 32).

Gunung Kemukus adalah sebuah dukuh atau dusun kecil berupa perbukitan. Bukit kecil ini termasuk wilayah Dusun Barong kelurahan/Desa Pendem Kecamatan Sumberlawang Kabupaten Sragen. Secara administratif Desa/Kelurahan Pendem terbagi dalarn 4 wilayah dusun yaitu : Dusun Barong, Dusun Pendem, Dusun Bulurejo, dan Dusun Ngabeyan. Gunung Kemukus berada di pinggir waduk buatan Kedungombo, yang luasnya mencakup Kabupaten Sragen, Boyolali, dan Purwodadi. Adapun batas-batas Gunung Kemukus Kelurahan Pendem pada Kecamatan Sumberlawang Kabupaten Sragen adalah: sebelah utara berbatasan dengan Desa Ngundul Kecamatan Sumberlawang; sebelah timur berbatasan dengan Desa Hadiluwih Kecamatan Sumberlawang; sebelah selatan berbatasan dengan Desa Soka Kecamatan Miri; Sebelah barat berbatasan dengan Desa Bagor Kecamatan Miri.

Dihitung dari jaraknya, Gunung Kemukus berada di sebelah barat Kota Sragen sekitar 35 kilometer, dan sebelah utara Kota Solo sekitar 27 kilometer. Jalur utama menuju Gunung Kemukus adalah jalur tranportasi berupa jalan aspal antar-kota yakni Solo-Purwodadi. Jalur ini adalah jalur yang paling mudah bagi pengunjung yang ingin mendapatkan berkah di 
makam Pangeran Samudra yang terletak di Gunung Kemukus tersebut. Saat penelitian dilakukan, sekitar 5 sampai dengan 10 menit sekali sarana transprotasi baik bus besar mini bus atau angkutan pedesaan melewati jalur ini. Selain angkutan tersebut masih ada angkutan lain berupa ojek. Apabila menuju Kemukus dari arah Surabaya harus menuju Solo dahulu, kemudian jurusan Purwodadi / Pati dan turun di Barong $(27 \mathrm{~km})$, kemudian naik ojek (+500 m) ke arah barat, dan naik tembo ( perahu) \pm 500 meter lagi. Demikian pula bila dari arah Yogyakarta atau Semarang langsung mengambil jurusan Solo.

\section{PEMBAHASAN}

A. Konsepsi Kosmologis dan Kosmogonis dalam Sistem Keyakinan

Sebuah sistem keyakinan dalam agama secara khusus dan religi secara umum, hampir selalu diwujudkan pada alam pikiran dan gagasan manusia yang berupa konsepsi manusia tentang sifat-sifat Tuhan serta wujud alam ghaib (Kosmologi). Sedangkan konsepsi tentang terjadinya alam semesta (kosmogoni) dari sebuah kelompok masyarakat dapat ditelusuri melalui sikap batin masyarakat yang bersangkutan pada saat mewujudkan sistem keyakinan.

Levis Strauss (Koentjaraningrat 2010; 226) mengatakan bahwa secara universal manusia dalam alam pikirannya merasa dirinya berhubungan dengan hal-hal tertentu pada alam semesta sekelilingnya serta berhubungan dengan manusia yang berada di lingkungan sosial budayanya. Dalam hubungan seperti itu menurut Levis Strauss manusia secara elementer mengklasifikasikan lingkungan alam semesta maupun lingkungan sosial budaya masing-masing yang terdiri dari hal-hal kolektif dan hal-hal yang bersifat khas atau khusus. Demikian halnya dengan pelaku ritual yang ada di Kemukus, dimana pelaku ritual merasa ada hubungan dengan kuburan yang dikeramatkan, sehingga apabila mitos dilakukan akan mempengaruhi dirinya.

Sesuai dengan kerangka teoritis Levis Strauss tadi, maka manusia melakukan pembagian atau pengklasifikasian alam semesta dan lingkungan sosial budaya yaitu dengan cara membagi alam semesta tersebut ke dalam dua golongan berdasar ciri-ciri yang saling bertentangan antara satu dengan yang lain, atau merupakan kebalikannya. Pembagian ke dalam dua golongan alam semesta tersebut bersifat mutlak berupa gejala alam seperti hidup/mati, kiri/kanan, depan/belakang, manusia/dewa, pria/wanita, hitam/putih, hal seperti ini disebutnya dalam istilah "binary oposition" atau oposisi berpasangan (Koentjaraningrat 2010; 229). 
Sementara itu keyakinan dan kesadaran manusia akan keterkaitannya berhubungan dengan lingkungan sosial dan alam semesta sekelilingnya tersebut, perlu ditindaklanjuti dan bukan hanya sekedar keyakinan dan kesadaran saja. Wujud dari tindak lanjut tersebut dicerminkan dengan sikap batin dan lahiriah dalam ritus-ritus upacara yang ada. Sedangkan upacara/ritual tersebut dilakukan untuk sejumlah kepentingan seperti halnya menginginkan ketenteraman, kedamaian dan ketertiban atau bahkan kekayaan sebagaimana yang dilakukan di Kemukus.

Pelaku ritual "ngalab berkah" di Gunung Kemukus mempunyai pandangan tersendiri tentang alam semesta ini. Apapun konsepsi tentang kosmologi yang dimilikinya, tentu tidak akan jauh berbeda dengan masyarakat Jawa pada umumnya di masa lampau. Masyarakat pelaku ritual "ngalab berkah" di Gunung Kemukus dengan etika jawa-nya tentu tidak akan terlepas pula dari unsur-unsur historis yang melatarbetakangi keberadaannya dalam komunitas jawa. Hal ini menjadi penting, karena konsepsi kosmologi dan kosmogoninya berawal ketika masyarakat Jawa belum mendapatkan ajaran-ajaran formal, dan dapat diketahui bahwa masyarakat Jawa pada saat itu, berada pada tingkat pertama evolusi religiusnya E.B. Tylor, (Koentjaraningrat 2010; 49) yakni pada masa "animisme dan dinamisme".

Simuh (1995) menguraikan tentang Islam masuk ke dalam masyarakat Jawa yakni ketika Islam mencoba masuk ke dalam masyarakat Jawa, para penyebar Agama Islam harus berhadapan dengan dua jenis kekuatan lingkungan budaya. Pertama, kebudayaan para petani lapisan bawah yang merupakan bagian terbesar yang hidup bersahaja dengan adat istiadat yang dijiwai oleh religius animisme dinamisme. Kedua, kebudayaan istana yang merupakan tradisi agung dengan unsurunsur filsafat Hindhu Budha yang memperkaya dan memperhalus budaya dan tradisi lapisan atas. Hal ini dapat dimaklumi karena setiap agama mengembangkan praktek atas kepercayaannya dalam komunitas masing-masing (Henslin, 2006. 164).

Berdasarkan budaya animisme dinamisme dan kebudayaan istana yang memuat unsur-unsur filsafat Hindu Budha pada masyarakat jaman dahulu inilah yang selanjutnya mempengaruhi konsepsi kosmogoni dan kosmologi pada masyarakat Jawa, termasuk di dalamnya masyarakat di Kemukus khususnya lagi pelaku ritual "ngalab berkah". Islam yang telah menjadi religi mayoritas masyarakat jawa tidak dipandang sebagai diabaikan dalam hal ini, tetapi dapat dipertemukan antara konsepsi umum dan khusus, atau antara konsepsi teoritis dan konsepsi aplikatif. Seperti tercantum dalam firman Allah (QS. Al-Mukmin: 64) bahwa Allah 
yang menjadikan bumi sebagai tempat menetap manusia dan langit sebagai atapnya. Begitu pula yang tercantum dalam firman Allah (QS. As Sajdah: 4) bahwa Allah yang menciptakan dunia dalam enam masa. Firman ini menjadi dasar kosmogoni Islam yang dalam pandangan pelaku ritual "ngalab berkah" merupakan konsep teoritis. Pandangan aplikatifnya adalah Allah menunjuk dan menggerakkan orang tertentu untuk melakukan pekerjaan tertentu, seperti menunjuk seseorang sebagai pemimpin (raja, presiden, gubernur, bupati dan lain-lainnya) dan diberikan kemampuan khusus untuk mengatur kehidupan di lingkungannya. Tentu saja konsepsi ini tidak semua pelaku ritual menyetujuinya, terlebih masyarakat Islam lainnya di luar pelaku aktivitas "ngalab berkah" di Kemukus. Pandangan lain akan menyebut hal ini sebagai hasil akulturasi dan sinkretisme Islam dan religi sebelumnya khususnya Hindu-Budha seperti gambaran Bousquet terhadap kondisi keagamaan Indonesia bahwa agama sinkretis sebagai agama sejati (Dadang, 2011. 46).

\subsection{Konsepsi Raja dan Hubungan Seks Bebas Sebagai Turut Nyonggo Wirang}

\section{A. Konsepsi Raja}

Bagi orang Jawa soal kepemimpinana atau kekuasaan raja bukan hanya sekedar tentang hasil kekayaan, pengaruh relasi, kekuatan fisik atau militer, kepintaran ataupun keturunan raja saja. Mencapai kekuasaan melalui faktor-faktor tersebut adalah usaha yang sia-sia, karena menurut orang Jawa untuk merebut kekuasaan tidak bisa dengan hal seperti itu, tetapi hanya dengan cara melalui pemusatan kekuatan kosmis dan kekuatan itu tidak bisa diambil melainkan dengan diberi. Sebagaimana dikatakan Frans Magnis Suseno (1996) bahwa dalam paham jawa, hal itu terjadi lewat pengalaman panggilan dan orang yang dipanggil ini biasanya sedang bermeditasi (semadi) di tempat yang keramat seperti puncak gunung atau ditengah hutan, atau yang sedang menjalani "Laku Topo Broto" (sedang menjalani tapa brata). Ketika orang sedang menjalani "topo broto" ini bagi yang berhasil biasanya tiba-tiba dijatuhi wahyu illahi dalam bentuk cahaya biru berbentuk bundar melayang-layang di langit tepat di atas orang yang melakukan "topo broto", kemudian turun tepat pada orang yang dipanggil tersebut. Cahaya biru itu sering disebut-sebut sebagai "ndaru" atau "pulung". Peristiwa ini dapat dilihat oleh orangorang yang melakukan "tirakatan", khususnya "tirakatan" ketika ada pemilihan pemimpin yang bakal dipilih untuk memimpin masyarakat tersebut seperti pemilihan kepala desa.Untuk itu, orang jawa punya 
keyakinan bahwa orang yang dipilih sang pencipta untuk memimpin suatu masyarakat bukanlah orang sembarangan, melainkan di dalam dirinya ada kekuatan Sang pencipta untuk mengatur manusia dan lingkungan sekitarnya.

Simuh (1999) mengatakan bahwa pandangan mengenai susunan alam semesta merupakan benua berbentuk lingkaran, yang dikelilingi oleh beberapa samudra dengan pulau-pulau besar di empat penjuru, yang merupakan tempat tinggal keempat penjaga yang keramat. Konsep ini diperjelas Simuh bahwa di pusat benua, terutama di Gunung Mahameru merupakan gunung para dewa dimana tempat Dewa Indra bersemayam sebagai raja para dewa. Dunia manusia diwakili oleh kerajaan dengan raja sebagai penjilmaan salah satu dewa yang mempunyai tugas untuk menjaga keselarasan kosmos, dengan cara meniru susunan alam semesta dalam kerajaannya. Kedudukannya di pusat kerajaan melambangkan raja dewa di pusat alam semesta. Sedangkan ke empat materi yang mengelilinginya adalah keempat permaisuri, dan para pegawai di keempat bagian kerajaannya melambangkan keempat mata angin dari alam semesta.

\section{B. Konsepsi Hubungan Seks Bebas dan Nyonggo Wirang}

Pelaku ritual meyakini bahwa dengan melakukan hubungan seks bebas di Kemukus merupakan bentuk kesetiaan seorang abdi dan rakyat terhadap keluarga raja. Pangeran Samudra merupakan seorang keluarga kerajaan Majapahit yang kemudian menjadi keluarga Keraton Demak dan sedang mendalami ilmu Agama ke Gunung Lawu karena perintah Raja Demak. Namun dalam perjalanannya kembali ke Demak mengalami gangguan kesehatan sehingga meninggal dalam perjalanan itu.

Selain itu, pelaku ritual juga meyakini bahwa hubungan seks bebas di sana merupakan bentuk "nyonggo wirang" atau turut menanggung malu atas hubungan yang dijalin antara Pangeran Samudra dengan R.A. Ontrowulan. Sebagian masyarakat mempercayai bahwa hubungan antara Pangeran Samudra dan R.A. Ontrowulan bukanlah hubungan anak dan ibu, melainkan antara kedua orang kekasih gelap. Sehingga bagi yang melakukan hubungan seks bebas adalah merupakan bentuk dari "nyonggo wirang" tersebut.

Dengan kesetiaan dan turut dalam "nyonggo wirang" tersebut maka pelaku ritual berharap bisa menepati makna mitos yang ada, sebagaimana dalam uraian sebelumnya bahwa mitos tersebut adalah kalimat yang telah diucapkan RA. Ontrowulan, yang maknanya bagi siapa saja yang datang ke kuburnya dan turut menanggung beban malu dengan cara melakukan seks dengan orang lain, maka akan dikabulkan keinginan orang tersebut. 
Keyakinan akan mitos ini tidak berdiri sendiri, namun berkaitan dengan konsepsi raja dalam kosmologi dan kosmogoni lama masyarakat jawa dan keyakinan bahwa orang mati tidaklah dianggap bahwa ruh atau jiwanya pergi ke akhirat, tetapi dipandang sebagai orang yang masih hidup tetapi berada di dunia lain dan memiliki kemampuan tertentu.

Eksistensi ritual menunjukkan bahwa keyakinan para pelaku ritual masih kuat dipengaruhi kepercayaan lama orang Jawa tentang kekuatankekuatan ghaib, khususnya sebelum mengenal Islam atau agama samawi lainnya. Kekuatan ghaib yang dimaksudkan adalah mengenai kekuatan luar biasa keluarga keraton khususnya konsepsi "raja" dalam pandangan orang Jawa (tertentu), dimana seorang raja diyakini sebagai manifestasi Tuhan sehingga berlaku sabdo pandito ratu (kata-kata raja merupakan hukum yang harus ditaati). Selain itu seorang raja juga diyakini sebagai Tuhan yang berwujud di dunia dan bertugas mengatur kehidupan nyata (Budiono, 2009. 174). Sehingga raja atau keluarganya diyakini mampu memberikan kesejahteraan bagi rakyatnya walaupun sudah mati. Karena mati pada dasarnya adalah mati secara fisik atau badan kasarnya saja.

Lapangan Pekerjaan dan Peningkatan Kesejahteraan Masyarakat

A. Lapangan Pekerjaan dan Kesejahteraan Masyarakat

Ritual mencari rejeki di Kemukus ini selain berdampak negatif yakni munculnya praktik prostitusi ternyata juga memberikan dampak positif. Salah satunya adalah memberikan mata pencaharian bagi warga masyarakat setempat. Masyarakat di Gunung Kemukus dan sekitarnya memiliki beberapa mata pencaharian akibat adanya pariwisata religi ini. Jika tidak ada pariwisata religi ini, masyarakat Kemukus akan kesulitan dalam mencari mata pencaharian sebagai penopang hidup keluarga. Daerah Gunung Kemukus sekitar makam Pangeran Samudera yang merupakan gunung sulit untuk dijadikan area pertanian, bahkan gunung ini dikelilingi waduk buatan yang meliputi 3 (tiga) kabupaten seperti Sragen, Purwodadi dan Boyolali.

Banyaknya pengunjung yang datang ke Gunung Kemukus, dan dengan ritual yang dilakukan hanya pada malam hari mampu memberikan inspirasi kepada masyarakat untuk memberikan fasilitas penginapan. Apalagi pengunjung yang datang biasanya dari jauh seperti Surabaya, Bandung dan kota-kota di pesisir pantai utara Jawa. Jauhnya pengunjung yang datang sangat memerlukan penginapan untuk menghilangkan rasa lelah dan kejenuhan selama perjalanan dan selama melakukan ritual. Penginapan yang dibuat warga masyarakat bukan hanya untuk pengunjung yang menginap saja, tetapi juga untuk melakukan ritus seks sebagai tahapan ritual "ngalab berkah" dengan seks 
bebas bagi yang mempercayai mitos. Hasil penelitian menunjukkan bahwa sejarah dari ritual ini sebelum ada bangunan rumah, para pengunjung yang melakukan ritus seks bebas melakukan hubungan intim di semak-semak. Sesuai perkembangan zaman, dan semakin banyaknya masyarakat Gunung Kemukus, maka warga kemudian mendirikan bangunan untuk memfasilitasi para pelaku ritual yang melakukan ritus hubungan seks agar tidak melakukan di semak-semak lagi. Jika ritus hubungan seks dilakukan di semak-semak, maka akan berakibat buruk pada anak-anak kecil yang selalu mondar-mandir di daerah itu. Keadaan ini dimanfaatkan warga untuk mendirikan penginapan dengan tujuan meminimalkan pengaruh buruk terhadap anak-anak, sekaligus mendatangkan kuntungan dari hasil sewa penginapan.

Selain mendirikan penginapan bagi pengunjung yang datang dari jauh dan sebagai tempat ritus hubungan seks, masyarakat juga membuka warung untuk mendapatkan penghasilan. Warung yang dibuka masyarakat adalah warung kopi, kelontong, dan sebagian masyarakat juga membuka warung makan. Makanan dan minuman sangat diperlukan oleh pelaku ritual, karena daerah ini dikelilingi waduk Kedungombo sehingga pengunjung tidak mungkin keluar area hanya untuk membeli makanan, minuman atau barang-barang lainnya. Dengan keberadaan warga masyarakat yang membuka warung akan sangat membantu pelaku ritual atau pengunjung sekaligus mendatangkan keuntungan bagi masyarakat setempat.

Salah satu benda yang sangat dibutuhkan pengunjung khususnya pelaku ritual adalah bunga mawar untuk ziarah di makam Pangeran Samudera. Peluang ini juga dimanfaatkan masyarakat Gunung Kemukus dan sekitarnya untuk menghasilkan uang dengan berjualan bunga mawar sebagai bunga tabur untuk ziarah. Banyaknya pengunjung yang melakukan ziarah ke makam Pangeran Samudra, memberikan peluang tersendiri bagi warga masyarakat untuk menjual bunga mawar untuk ziarah. Pada masyarakat Jawa, berziarah identik dengan menaburkan bunga mawar di atas pusara orang yang meninggal setelah melakukan doa. Khusus di makam Pangeran Samudera dan tokoh lainnya, ziarah dilakukan secara islami karena Pangeran Samudera merupakan kerabat Keraton Demak yang merupakan kerajaan Islam di Jawa Tengah. Untuk ziarah ini difasilitasi juru kunci yang bertindak semacam teungku bagi orang Aceh, tetapi juru kunci ini khusus untuk ziarah. Dengan demikian bagi yang tidak paham doa ziarah, atau bagi yang beragama lain doanya dipimpin juru kunci.

Selain itu, warga juga menjual botol plastik kosong seperti botol bekas air aqua atau jerigen. Botol ini akan dimanfaatkan pengunjung 
untuk menampung air dari sendang Ontrowulan. Sebagian besar pelaku ritual mempercayai air sendang Ontrowulan bisa menyembuhkan penyakit. Sebagian lagi percaya bahwa dengan air tersebut lebih mudah terkabul, karena sendang ini merupakan tempat RA. Ontrowulan mensucikan diri sebelum meninggal di atas pusara Pangeran Samudera (sebagian menganggap moksa), sehingga pelaku ritual dari luar daerah bersedia membeli botol atau jerigen kosong untuk diisi air sendang tersebut. Hal ini merupakan mata pencaharian yang juga menjanjikan kesejahteraan bagi penjual botol kosong tersebut. Sebagian lagi ada yang menawarkan jasa untuk mengambil air dari dalam sendang yang kebanyakan orang menyebut seperti ini sebagai sumur.

Mata pencaharian lainnya yang dapat diperoleh oleh masyarakat Gunung Kemukus adalah penitipan sandal dan sepatu bagi para pengunjung. Untuk masuk ke tempat makam Pangeran Samudera tidak diperbolehkan menggunakan alas kaki, sehingga sepatu maupun sandal harus dilepaskan. Banyaknya sepatu dan sandal yang berserakan dapat mengakibatkan salah dalam mengambilnya (bisa jadi disengaja oleh orang tertentu dan dengan maksud tertentu pula), untuk itu agar tidak keluar area tanpa alas kaki maka pengunjung sebaiknya menitipkan pada petugas yang menjaga penitipan. Banyaknya pengunjung yang terpaksa menitipkan, maka hal ini juga menjadi mata pencaharian tersendiri.

Serupa penitipan sandal dan sepatu, juga ada layanan tempat parkir, layanan penyeberangan dengan perahu, layanan transportasi berupa ojek. Sesekali juga dijumpai warga masyarakat yang mengadakan hiburan berupa permainan sulap atau hiburan lainnya. Dengan demikian dapat dipastikan bahwa keberadaan ritual di Gunung Kemukus dapat mendatangkan lapangan pekerjaan dan kesejahteraan masyarakat.Hal ini dapat dipastikan penutupan tempat ini sebagai kawasan wisata religi dapat berdampak pada banyaknya keluarga yang bakal kehilangan mata pencaharian dan menjadi kelaparan.

\section{Pendapatan Bagi Pemerintah}

Bukan hanya masyarakat Gunung Kemukus dan sekitarnya yang mendapatkan penghasilan, pemerintah Kabupaten Sragen melalui Dinas Pariwisata juga mendapatkan pemasukan dari tiket wisata religi ini. Dinas pariwisata memasang portal pada pintu masuk Gunung Kemukus, dan menjual karcis untuk masuk ke area wisata. Pelaku ritual yang berasal dari jauh dan membawa kendaraan sendiri akan melewati pintu portal dinas pariwisata. Tetapi pengunjung atau pelaku ritual yang menggunakan angkutan umum seperti bus akan melalui jalur Barong. Di 
jalur ini akan banyak dijumpai warga masyarakat yang berprofesi sebagai tukang ojek, yang khusus mengantarkan pengunjung atau pelaku ritual ke Gunung Kemukus.

Dinas pariwisata tidak menguasai atau mengelola seluruh daerah di Gunung Kemukus. Untuk itu dibuat pagar pembatas antara tanah yang dikelola Dinas pariwisata dengan tanah warga masyarakat. Di dalam area dinas pariwisata terdapat mushola untuk memberikan layanan bagi pengunjung muslim yang ingin melakukan shalat. Tetapi penempatan petugas untuk menarik karcis masuk bukan berada di batas pagar tersebut. Petugas penarik karcis berada di luar atau di perbatasan memasuki Gunung Kemukus. Tetapi intinya adalah bahwa setiap orang yang memasuki Gunung Kemukus akan dikenakan karcis sehingga memberikan pendapatan bagi pemerintah. Sedangkan masyarakat mendapatkan penghasilan dari usahanya sendiri sebagaimana tersebut di atas.

\section{KESIMPULAN}

Keyakinan mengenai konsep raja sebagai manifestasi Tuhan, dimana Tuhan merupakan pencipta alam semesta dengan segala peristiwa yang meliputinya. Dengan dekat kepada raja sama artinya dekat dengan Tuhan. Dekat dengan Tuhan maka apa yang menjadi keinginannya akan lebih mudah dikabulkan. Konsepsi "nyonggo wirang" atau turut menanggung malu atas aib yang dilakukan Pangeran Samudra dan R.A. Ontrowulan bagi pelaku ritual yang mempercayai, merupakan bentuk kedekatan pelaku ritual dengan sang tokoh. Dalam konsep "yonggo wirang" ini, pelaku ritual dengan seks bebas meyakini bahwa hubungan antara R.A Ontrowulan dengan Pangeran Samudra adalah hubungan perselingkuhan, bukan hubungan antara anak dan ibu sebagaimana cerita yang tertulis dalam sejarah Gunung Kemukus versi Dinas Pariwisata, sehingga apabila seseorang melakukan hubungan seks bebas tersebut dianggap "nyonggo wirang" dan akan dikabulkan keinginannya. Dengan mitos ini maka berbondong-bondong orang menuju Gunung Kemukus untuk melakukan ritual "ngalab berkah" dengan melakukan seks bebas.

Dampak dari banyaknya orang yang menuju Gunung Kemukus untuk melakukan ritual menjadi inspirasi tersendiri bagi warga masyarakat. Berbagai kebutuhan pelaku ritual seperti penginapan, bunga tabur, penitipan kendaraan (parkir), penitipan sepatu/sandal, penjualan botol, jasa timba air sendang, warung makan dan minum, dan kebutuhan lainnya dipenuhi masyarakat, sehingga hal ini mendatangkan mata pencaharian tersendiri bagi warga masyarakat. 


\section{PUSTAKA}

Abdul Aziz Ahyadi, 2005. Psikologi Agama: Kepribadian Muslim Pancasila. Bandung. Sinar Baru Algensindo.

Anton Bakker, 2004. Antropologi Metafisik. Yogyakarta. Kanisius

Bernard Raho, 2014. Sosiologi. Maumere. Ledalero

Budiono Hadisutrisno, 2009. Islam Kejawen. Yogyakarta. Eule Book.

Dadang Kahmad, 2011. Sosiologi Agama Potret Agama dalam Dinamika Konflik, Pluralisme dan Modernitas. Bandung. Pustaka Setia.

Henslin, James M., 2006. Sosiologi Dengan Pendekatan Membumi. Edisi 6. Jilid 2. Alih Bahasa: Kamanto Sunarto. Jakarta. Erlangga.

Koentjaraningrat. 2010. Sejarah Teori Antropologi I. Jakarta: Universitas Indonesia.

Simuh. 1999. Sufisme Jawa Transformasi Tasawuf Islarn ke Mistik Jawa. Cetakan ketiga. Yogyakarta: Yayasan Bentang Budaya.

Havilan W.A. 1995. Antropologi I Edisi 4. Jakarta. Penerbit Erlangga. 1998. Antropologi II. Jakarta: Penerbit Erlangga.

M. Adnan Hanafiah dkk, 2000. Kamuih Aceh-Indonesia-Inggreh: EnglishIndonesia-Acehnese Dictionary. Banda Aceh. Dinas Pendidikan dan Kebudayaan Propinsi Daerah Istimewa Aceh.

Magnis Susena, Frans. 1996. Etika Jawa Sebuah analisa Falsafi Tentang Kebijaksanaan Hidup Jawa. Cetakan ke enam. Jakarta: PT. Gramedia Pustaka Utama.

Sindung Haryanto, 2015. Sosiologi Agama Dari Klasik Hingga Postmodern. Yogyakarta. Ar-Ruzz Media.

Triyanto. 2000. Fungsi Ritus Hubungan Seks Bebas Pada Upacara Memohon Rejeki di Gunung Kemukus Kabupaten Sragen Jawa Tengah. Jurusan Antropologi Fakultas Sastra Universitas Udayana. Denpasar 